\title{
Assessment of the Effect of Organizational Support and Investment in Employee Development on Affective Commitment
}

\author{
Kossivi Bodjrenou ${ }^{1}, \mathrm{Xu} \mathrm{Ming}^{2}$ \\ ${ }^{1} \mathrm{PhD}$ Candidate, Glorious Sun School of Business and Management, Donghua University, Shanghai, China \\ ${ }^{2}$ Professor, Glorious Sun School of Business and Management, Donghua University, Shanghai, China \\ Correspondence: Kossivi Bodjrenou, Sun School of Business and Management, Donghua University, Shanghai, \\ 1882 West Yan'an Road, Shanghai, China.
}

Received: January 9, 2019

Accepted: February 12, 2019

Online Published: February 20, 2019

doi:10.5539/ibr.v12n3p153

URL: https://doi.org/10.5539/ibr.v12n3p153

\begin{abstract}
The purpose of this research is to identify factors and conditions that improve the affective commitment of employees so as to increase the chances of organizations to retain their employees. This research took the form of a multiple regression analysis and assessed the ability of Perceived Investment in Employee Development and Perceived Organizational Support to predict Affective Commitment controlling nationality. The Perceived Investment in Employee Development questionnaire, Perceived Organizational Support assessment tool, and Affective Commitment survey have been utilized as instruments to collect data and a nonprobability purposive sampling technique involving 250 full-time employees in the service industry in Shanghai was carried out.

It was observed that Perceived Investment in Employee Development and Perceived Organizational Support are significant predictors of Affective Commitment among various categories of employees that were distinguished in this study. It was found that employees welcome developmental programs where Perceived Organizational Support is high. It was suggested that endeavors to retain employees in China should not just implement observations made in Western countries but consider the socio-economic realties of the country so as to be effective. More light needs to be thrown on the predictors of Affective Commitment in China and this research recommended areas that require further investigations.
\end{abstract}

Keywords: affective commitment, perceived organizational support, perceived investment in employee development, leadership culture, demographic characteristics, organization characteristics

\section{Introduction}

In today's business world employees are important to an organization and their significance is unquestionable. Employees are the most valuable assets of a business (Mita, Aarti \& Ravneeta, 2014) and for Bidisha (2013), "human resources are the life-blood of any organization". The value of an employee to an organization increases more with time, as he or she gains experience and becomes more productive on the job (Odubanjo, 2015). The advancement in technology that has caused most organizations to be more and more technology-driven does not reduce the significance of employees because machines cannot operate on their own (Bidisha, 2013). However, it is becoming increasingly challenging for businesses to keep their staff due to competition (Mita, Aarti \& Ravneeta, 2014). The biggest challenge of organizations worldwide is their inability to keep their staff for the longest possible time (Bidisha, 2013). China is not exempt from this problem. In 2016 voluntary turnover in China has been estimated to $14.06 \%$, which is $6.21 \%$ and $7.21 \%$ higher than South Korea and Japan respectively (Mercer, 2016). Average turnover rate is on the rise, 16.7\% in 2012 and $17.7 \%$ in 2015 (China Daily USA, 2015). In 2016, for $75 \%$ of employees surveyed in the Mainland it is likely that they would change jobs within 12 months (Michaelpage, 2016). Because the employee retention challenge in China is stronger than that of neighboring counties one may question if expatriates workers also constantly change their job.

Generally speaking people quit their job because of their supervisor (Maxwell, 2011). Zhang, Tsingan, \& Zhang (2013) observed that poor leadership practice affects employee commitment to the organization and eventually the decision to leave. However, Harter \& Adkins, (2015) observed that the majority of leaders do not have the expertise needed to improve employees' commitment to the organization and engagement in their work. Low level of commitment is predictor of turnover (Thirapatsakun, Kuntonbutr, \& Mechinda, 2014). In China the main 
reason why employees quit their job is absence of career progression or promotion opportunities (Michaelpage, 2016). Supervision and career progression are relational and developmental issues. In the quest to assess the relation that organizations have with the employees Rhoades \& Eisenberger (2002) came out with the concept of Perceived Organizational Support (POS) and the POS survey has been widely used by many scholars to investigate this relation. As far as development is concerned, Perceived Investment in Employee Development instrument (PIED) has also been used worldwide to ascertain developmental effort made by employers, viewed from employees' perspective (Lee \& Bruvold, 2003; Kuvaas \& Dysvik, 2009; Kuvaas, Dysvik \& Buch, 2016).

The objective of this research is to evaluate the abilitiy of POS and PIED to predict employees organizational commitment so as to increase the chances of organizations to retain their employees. This study also seeks to know if the retention problem faced by organizations in China affects only Host-Country Nationals (HCN) or also expatriates workers. In order to achieve these objectives this investigation attempted to answer the following questions:

Q1: What is the effect of nationality on Perceived Organizational Support?

Q2: What is the effect of nationality on Perceived Investment in Employee Development?

Q3: What is the effect of Perceived Organizational Support and Perceived Investment in Employee Development on affective commitment?

\section{Literature Review}

\subsection{Organizational Commitment}

Mowday, Porter and Steers (1982) described the concept of organizational commitment as "the process by which individuals become locked into a certain organization". For Meyer \& Allen (1997) organizational commitment is the emotional response expressed by employee's behaviors, beliefs, and attitudes. It is a psychological state that expresses the degree of affiliation of an employee to an organization. Meyer \& Allen (1991) developed a tri-dimensional concept to describe organizational commitment and termed it the Three Component Model (TCM). The dimensions of the Three Component Model (TCM) are: Affective Commitment, Continuance Commitment, and Normative Commitment. They defined affective commitment as "positive feelings of identification with, attachment to and involvement in the work organization", continuance commitment as "the extent to which employees feel committed to their organization by virtue of the costs that they feel are associated with leaving", and normative commitment as "the employee's feelings of obligation to remain with the organization".

As far as the consequences of organizational commitment are concerned it has been observed that it is almost impossible for an organization to be successful without the commitment of its workforce (Mosadeghrad, Ferlie \& Rosenberg, 2008) and Lok \& Crawford (2004) noticed that organization effectiveness is strongly dependent on employee commitment. Organizational commitment is a major determinant to attracting and retaining qualified labor (Mosadeghrad, Ferlie \& Rosenberg, 2008). Organizational Commitment enhances the performance of individual employees as well. Committed employees are more motivated and "go the extra mile" in contributing to the achievement of organization goal (Meyer \& Allen, 2004). The concept has also been associated with employee stability. In that line, many scholars observed that the commitment of employee to the organizations improves employee stability and reduces the cost of turnover (Meyer, Stanley, Herscovitch, \& Topolnytsky, 2002; Meyer \& Allen, 2004). Meyer \& Allen (2004) were more specific about the relation between Employee Commitment and Stability. They observed that "employees with a strong affective commitment stay because they want to, those with strong normative commitment stay because they feel they ought to, and those with strong continuance commitment stay because they have to do so".

Normative and continuance commitments are respectively related to the personal ethic, moral or ideology and the costs associated with quitting one's job. These factors are beyond the control of organizations as people's personal ethic, moral or ideological stance cannot be easily changed and the cost of leaving is subject to what competitors are willing to offer to attract labor. Affective commitment was linked to positive feeling of identification to the mission, vision, goal, policies of the organizations. These factors can be influenced to positively impact this type of commitment of employees towards their organization by recruiting people with the same vision, and adjusting to meet their needs. Because organizations cannot really influence normative and continuance commitment, affective commitment was chosen to research on, as so to identify ways business entities could increase it in order to ultimately improve firms' ability to retain their workforce.

Scholars endeavored to identify factors that could influence affective commitment. Some personal or individual-level variables such as age, personality, education or values orientation were identified by Kate and 
Masako (2002) as influential factors of affective commitment. Allen \& Meyer (1997) also observed that affective commitment of employees could be influenced by demographic factors such as age, gender, nationality, education level, marital status and tenure. While the results of some previous studies showed no relation between commitment and gender (Bruning \& Snyder, 1983), other observations evidenced otherwise. They explained their finding that women are less committed than men by the family responsibility that the latter gender carries (Loscocco, 1990). Investigations also found that women have a higher level of commitment than men do (Mathieu \& Zajac, 1990). Assessing commitment on the basis of age or generation Bokor et al. (2007) and (Mathieu \& Zajac (1990) found that the older the employee the higher the commitment.

Investigations on affective commitment scrutinized from nationality perspective carried out in previous studies reported possible dissimilarity in the level of commitment based on nationality even though this difference is not systematic (Gelade, Dobson \& Gilbert, 2006).

Previous research works have confirmed that demographics or individual-level variables relates to organizational commitment particularly in Western countries where these studies have been carried out. This leads to the following hypothesis:

H1: Employees' nationality affects their affective commitment to their organization.

\subsection{Perceived Organizational Support}

Rhoades and Eisenberger (2002) defined Perceived Organizational Support (POS) as "employees' general belief that their work organization values their contribution and cares about their well-being". For George et al. (1993) POS is the assurance that help will be offered by the employer whenever needed to do to job and in tense situations. POS resulted from employees' tendency to personify organizations (Eisenberger et al., 1986). The personification of organization occurs when employees view the actions of the stewards as the intent of the entity. Zhang, Farh \& Wang (2012) viewed POS as "the quality of the reciprocal social exchange taking place between the employees and the organization". POS was also viewed from the perspective of reciprocity norm. As such, when employers give a good treatment to their workforce, employees reciprocate by being engaged in their job. In line with the reciprocity norm POS has been linked to many other notions.

POS has been associated with many other related concepts such as leader-member exchange (Settoon et al., 1996), and job satisfaction (Eisenberger et al., 1997). Eisenberger et al. (1986) pointed out that potential influencers of POS could be rewards, position, job enrichment and organizational policies. Chen et al (2005) found that POS affects employee's intention to leave their employer. Armeli et al., (1998) observed that POS positively relates to employee performance on the job. POS has been identified by many scholars as a predictor of affective commitment (Shore and Wayne 1993; Rhoades, Eisenberger and Armeli 2001; Chen, Aryee and Lee 2005). POS has also been associated with individual-level variables and Qammar, Khan and Siddique (2006) supported that gender does not correlate with Perceived Organizational Support. Rayani (2015) observed a generational difference in Perceived Organizational Support but Rhoades and Eisenberger (2002) reported the contrary. Although Black, Mendenhall. \& Oddou (1991) pointed out that expatriates are different from Host Country National employees, on the basis of the psychological uncertainty and practical adjustments of the former, Bashir (2012) and Takeuchi et al. (2009) have not observed on the subject a distinctive difference between the POS of these two categories of employees. On the basis of the above literature it has been hypothesized that:

H2: Employees' nationality affects Perceived Organizational Support.

\subsection{Perceived Investment in Employee Development}

The concept of Perceived Investment in Employee Development (PIED) has been defined as the endeavor of an organization to equip its employees with additional knowledge and skills so as to enable to them to be ready to take on high responsibilities either with their current employer or new organizations (Rothwell and Kazanas, 1989). Lee and Bruvold (2003) explained the notion of PIED as being the continuous or sustained effort made by an organization "to help employees learn to identify and obtain new skills and competencies that will allow them to move to new positions, either within or outside the organizations".

PIED plays an important role in motivating, developing and retaining employees and has a significant positive impact on the performance of the individuals and the organization as a whole (Lee and Bruvold, 2003). PIED gives employee a positive feeling of adding value to their organization. PIED has been associated with many other related concepts and either it is formally or informally implemented, the outcomes remain significant. Arthur (1994) and Woods \& de Menezes (1998) found that PIED plays a majors role in the motivation and performance of employees. PIED has been positively related to employee retention (Gutteridge et al., 1993). Reich (1991) reported that PIED affect positively an organization's competitiveness and can be used as a means 
to gain competitive advantage.

Many scholars did not only associate PIED with motivation and performance but also related it with organizational commitment (Ichniowski et al., 1997; Youndt et al., 1996; MacDuffie, 1995). Lee and Bruvold (2003) observed that PIED is positively associated with affective commitment but not continuous commitment. They also found the individual-level variables have a mediation effect on the relation between PIED and affective commitment. On the basis it was hypothized that:

H3: Employees' nationality affects Perceived Investment in Employee Development.

As indicated in the sections 2.1, 2.2 and 2.3 POS, PIED, individual-level variables such as gender, age and nationality have been associated with affective commitment. On the basis of these research works it has been hypothesized that:

H4: The relation between Perceived Organizational Support and Perceived Investment in Employee Development, and affective commitment is affected by the nationality of employees.

\section{Method}

\subsection{Conceptual Framework}

The purpose of this research is to evaluate the abilitiy of POS and PIED to predict employees organizational commitment so as to increase the chances of organizations to retain their employees. This study also seeks to know if the retention problem faced by organizations in China affects only Host-Country Nationals (HCN) or also expatriates workers. The conceptual framework below was proposed to comprehend the antecedents of affective commitment.

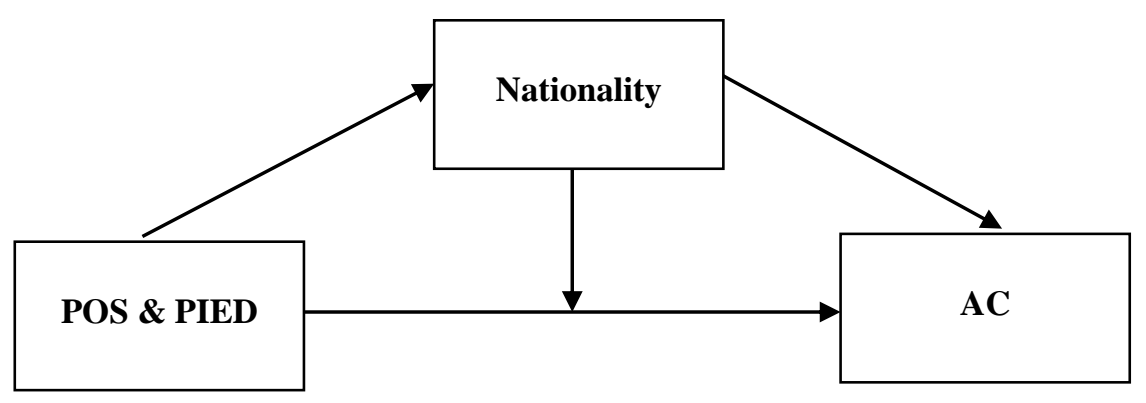

\section{Conceptual Framework}

\subsection{Research Method and Instrument}

This study took on a multiple regression analysis design. It examined the results of a survey to answer the research questions by appraising the hypotheses developed for the sake of this investigation. The study made use of Perceived Organizational Support, the Perceived Investment in Employee Development and the Affective commitment surveys. Furthermore a T-test was carried out to evaluate the level of organization commitment, strength of Perceived Organizational Support, and Perceived Investment in Employee Development effort among $\mathrm{HCN}$ and expatriate workers.

The Affective Commitment compomemt is a part of the Three Component Model (TCM) Employee Commitment Survey (Meyer \& Allen, 2004), which is originally made up of three components, affective commitment, continuance commitment, and normative commitment. The second component of the survey is Perceived Organizational Support portion which comprises of four items and assesses employer-employee relationship viewed from the perceptive the employee. The last component is Perceived Investment in Employee Development part which is made up of seven items. All the three components are made up of items with a 7-point Likert scale: (1) strongly disagree, (2) disagree, (3) slightly disagree, (4) undecided, (5) slightly agree, (6) agree and (7) strongly agree.

\subsection{Data collection and Organization Techniques}

A nonprobability purposive sampling technique involving 250 full-time employees in the service industry in Shanghai was carried out in the data collection process. The survey initially designed in English was translated in Chinese. The Chinese translation went through a double review before the final survey was issued. The final 
version was available online and it was also printed out in both languages. The platforms of SurveyMonkey and wjx.cn were utilized to reach out to other participants. The survey was also printed out and handed to employees to fill in. Data collected through printouts were input in an Excel spreadsheet. After review the file was merged with the SurveyMonkey and wjx.cn data. Through three means in all, 250 respondents took part in the survey from January to April 2018.

The facts collected in the data gathering process were prepared for analysis through coding and converting the format into one that can be easily analyzed. Each respondents was attributed an alphanumerical code ranging from R001 to Rxxx, xxx representing the number of respondents based the assumption that the participants will be less inferior or equal to 999. A three-digit alphanumeric code was used to the questions. The code ranged from $\mathrm{Q} 01$ to $\mathrm{Qxx}, \mathrm{xx}$ representing the number of questions.

\section{SPSS 21.}

\subsection{Sample Size}

To ensure the representativeness of the sample size in order to guarantee external validity so as to generalize the conclusion, $\mathrm{G}^{*}$ Power 3 used to estimate the minimum number of participants. The 250 sample size obtained exceeded the estimated size of 123 responses. $G *$ Power 3.1.9.2 was used to determine the sample size. Using an alpha level of 0.05 , a power of .99 , and an effect size of 0.13 , the required size to find significance with 10 predictors is 123.

\subsection{Participant Characteristics}

The population chosen for this research is the employees in the service sector in Shanghai. The participants are full-time employees with a minimum of 18 years old. Self-employed individuals are excluded. In the research questionnaire each participant was requested to report the following demographic information: gender, age, nationality and the industry of current organization. 135 women and 115 men representing respectively $54 \%$ and $46 \%$ took part in the study. The sample is categorized of 2 age-groups, generation $\mathrm{X}$ (below 37 years old) and $\mathrm{Y}$ (above 37 years old). Gen X represented 66\% and Gen Y 34\% respectively. 80\% of the respondents are HCNs and the remaining $20 \%$ of them are expatriates working. $3 \%$ of the employees surveyed work in the transport in industry, $4 \%$ in the medical field, 18 in the financial sector, $23 \%$ in the education sector and $52 \%$ are from other industries.

\section{Results}

\subsection{Cronbach's Alpha Reliability}

Perceived Organizational Support scale with 4 items reported an alpha reliability of .800 as compared to .970 reported by Eisenberger et al., (1986). Perceived Investment in Employee Development with 7 items reported a Cronbach alpha of .861 as compared to .880 reported by Tuck (2014). Affective Commitment with 6 six items reported an alpha reliability of .895 as compared to Krishnaveni \& Ramkumar (2008). All the scales reported a high reliability level as the threshold is .7 (Lehmann et al., 2005 and Yunus 2010).

\subsection{A Comparative Analysis of Affective Commitment against Nationality}

An independent-samples t-test was conducted to compare affective commitment for HCNs and expatriate workers. There was no significant difference in the scores for national and expatriate employees (Table $1 \&$ Appendix A).

Table 1. Affective commitment-Nationality Group Statistics

\begin{tabular}{llcccc}
\hline & Nationality & $\mathrm{N}$ & Mean & Std. Deviation & Std. Error Mean \\
\hline \multirow{2}{*}{ AC } & Chinese & 200 & 4.9944 & 1.37351 & .09712 \\
& Foreigner & 50 & 5.0435 & 1.66231 & .23509 \\
\hline
\end{tabular}

\subsection{A Comparative Analysis of Perceived Organizational Support Score Against Nationality}

An independent-samples t-test was conducted to compare Perceived Organizational Support score for HCNs and expatriate employees. There was no significant difference in the scores of local employees $(M=4.4441$, $\mathrm{SD}=1.16318)$ and expatriates $(\mathrm{M}=4.4022, \mathrm{SD}=1.40380) ; \mathrm{t}(248), \mathrm{p}(.0828)>.05$ (Table $2 \&$ Appendix $\mathrm{B})$.

Table 2. POS-Nationality Group Statistics

\begin{tabular}{llcccc}
\hline & Nationality & $\mathrm{N}$ & Mean & Std. Deviation & Std. Error Mean \\
\hline \multirow{2}{*}{ POS } & Chinese & 200 & 4.4441 & 1.16318 & .08225 \\
& Foreigner & 50 & 4.4022 & 1.40380 & .19853 \\
\hline
\end{tabular}




\subsection{A Comparative Analysis of Perceived Investment in Employee Development Score against Nationality}

An independent-samples t-test was conducted to compare Perceived Investment in Employee Development score for national and expatriate employees. There was no significant difference in the scores of local employees $(\mathrm{M}=$ 4.2119, $\mathrm{SD}=1.09703)$ and expatriates $(\mathrm{M}=3.9860, \mathrm{SD}=1.22177) ; \mathrm{t}(248), \mathrm{p}(.204)>.05$ (Table 3 \& Appendix $\mathrm{C})$.

Table 3. PIED-Nationality Group Statistics

\begin{tabular}{llcccc}
\hline & Nationality & $\mathrm{N}$ & Mean & Std. Deviation & Std. Error Mean \\
\hline \multirow{2}{*}{ PIED } & Chinese & 200 & 4.2119 & 1.09703 & .07757 \\
& Foreigner & 50 & 3.9860 & 1.22177 & .17278 \\
\hline
\end{tabular}

\subsection{Assessment of the Effect of POS and PIED on AC}

A Multiple Regression Analysis was calculated to predict Affective Commitment based on Perceived Organizational Support and Perceived Investment in Employee Development. A significant regression equation was found $(\mathrm{F}(2,247)=210.034$, p <.000), with an R2 of.630. Employees predicted Affective Commitment is equal to. $387+.277$ (PIED) +.780 (POS). This shown is Tables 4, 5, and 6 below.

Table 4. POS-PIED-AC Model Summary

\begin{tabular}{lcccc}
\hline Model & $\mathrm{R}$ & R Square & Adjusted R Square & Std. Error of the Estimate \\
\hline 1 & $.794^{\mathrm{a}}$ & .630 & .627 & .87516 \\
\hline a. Predictors: (Constant), PIED, POS & & &
\end{tabular}

Table 5. POS-PIED-AC ANOVA ${ }^{\mathrm{a}}$

\begin{tabular}{llccccc}
\hline Model & & Sum of Squares & df & Mean Square & F & Sig. \\
\hline \multirow{2}{*}{1} & Regression & 321.734 & 2 & 160.867 & 210.034 & $.000^{\mathrm{b}}$ \\
& Residual & 189.180 & 247 & .766 & & \\
& Total & 510.915 & 249 & & & \\
\hline
\end{tabular}

a. Dependent Variable: AC

b. Predictors: (Constant), PIED, POS

Table 6. POS-PIED-AC Coefficients ${ }^{\mathrm{a}}$

\begin{tabular}{|c|c|c|c|c|c|c|}
\hline \multicolumn{2}{|c|}{ Model } & \multicolumn{2}{|c|}{ Unstandardized Coefficients } & \multirow{2}{*}{$\begin{array}{c}\text { Standardized } \\
\text { Coefficients } \\
\text { Beta } \\
\end{array}$} & \multirow[t]{2}{*}{$\mathrm{t}$} & \multirow[t]{2}{*}{ Sig. } \\
\hline & & B & Std. Error & & & \\
\hline \multirow{3}{*}{1} & (Constant) & .387 & .242 & & 1.603 & .110 \\
\hline & POS & .780 & .053 & .660 & 14.685 & .000 \\
\hline & PIED & .277 & .057 & .218 & 4.839 & .000 \\
\hline
\end{tabular}

a. Dependent Variable: AC

The preliminary assessment of the combined effect of Perceived Organizational Support and Perceived Investment in Employee Development on Affective Commitment reveals that POS and PIED were significant predictors of AC.

\subsection{The Effect Nationality on the Relation between POS, PIED and AC}

A multiple linear regression analysis was carried out to predict Affective Commitment based on Organizational Support and Perceived Investment in Employee Development controlling for the nationality of the employees. For the sake of this investigation only two categories, Host Country Nationals (HCN) and expatriates workers, were considered.

\subsubsection{Host Country Nationals (HCN) Employees}

A multiple linear regression was conducted to predict Affective Commitment based on Organizational Support and Perceived Investment in Employee Development among Chinese employees. A significant regression equation was found $(\mathrm{F}(2,197)=170.062 \mathrm{p}<.000)$, with an $\mathrm{R} 2$ of .633. Chinese employees predicted Affective Commitment is equal to $.349+.300$ (PIED) +.761 (POS). This is shown in Table 7, 8 and 9 below. 
Table 7. HCN PIED-POS-AC Model Summary

\begin{tabular}{lcccc}
\hline Model & $\mathrm{R}$ & R Square & Adjusted R Square & Std. Error of the Estimate \\
\hline 1 & Nationality $=$ & & .83603 \\
\hline a. Predictors: (Constant), PIED, POS & .633 & .630 & .836 (Selected) \\
\hline
\end{tabular}

Table 8. HCN PIED-POS-AC ANOVA ${ }^{\mathrm{a}, \mathrm{b}}$

\begin{tabular}{llcccc}
\hline Model & & Sum of Squares & df & Mean Square & F \\
\hline \multirow{2}{*}{1} & Regression & 237.726 & 2 & 118.863 & 170.062 \\
& Residual & 137.691 & 197 & .699 & $.000^{\mathrm{c}}$ \\
& Total & 375.417 & 199 & & \\
\hline
\end{tabular}

a. Dependent Variable: AC

b. Selecting only cases for which Nationality $=$ Chinese

c. Predictors: (Constant), PIED, POS

Table 9. HCN PIED-POS-AC Coefficients ${ }^{\mathrm{a}, \mathrm{b}}$

\begin{tabular}{lllllll}
\hline Model & & \multicolumn{2}{l}{ Unstandardized Coefficients } & \multicolumn{2}{l}{$\begin{array}{l}\text { Standardized } \\
\text { Coefficients } \\
\text { Beta }\end{array}$} \\
& & B & Std. Error & Sig. & \\
\hline \multirow{2}{*}{1} & (Constant) & .349 & .267 & & 1.305 & .193 \\
& POS & .761 & .060 & .644 & 12.760 & .000 \\
& PIED & .300 & .063 & .240 & 4.749 & .000 \\
\hline
\end{tabular}

a. Dependent Variable: AC

b. Selecting only cases for which Nationality $=\mathrm{HCN}$

The multiple regression analysis carried out among HCN employees to investigate whether POS and PIED could significantly predict their AC scores indicates that the model explained $63.3 \%$ of the variance and that it is a significant predictor of Affective Commitment.

\subsubsection{Expatriates}

A multiple linear regression was conducted to predict Affective Commitment based on Organizational Support and Perceived Investment in Employee Development among foreign employees. A significant regression equation was found $(\mathrm{F}(2,47)=39.689 \mathrm{p}<.000)$, with an $\mathrm{R}^{2}$ of .628 . Expatriates employees predicted Affective Commitment is equal to $.491+.230$ (PIED) +.826 (POS). This is shown in Tables 10, 11 and 12 below.

Table 10. Expatriates PIED-POS-AC Model Summary

\begin{tabular}{clcccc}
\hline Model & $\begin{array}{l}\mathrm{R} \\
\text { Nationality }=\end{array}$ & Foreigner (Selected) & R Square & Adjusted R Square & $\begin{array}{l}\text { Std. } \\
\text { Estimate }\end{array}$ \\
\hline 1 & $.793^{\mathrm{a}}$ & .628 & .612 & of the \\
\hline
\end{tabular}

a. Predictors: (Constant), PIED, POS

Table 11. Expatriates PIED-POS-AC ANOVA ${ }^{\mathrm{a}, \mathrm{b}}$

\begin{tabular}{lllllll}
\hline Model & & Sum of Squares & df & Mean Square & F & Sig. \\
\hline \multirow{2}{*}{1} & Regression & 85.045 & 2 & 42.523 & 39.689 & $.000^{\mathrm{c}}$ \\
& Residual & 50.356 & 47 & 1.071 & & \\
& Total & 135.401 & 49 & & & \\
\hline
\end{tabular}

a. Dependent Variable: AC

b. Selecting only cases for which Nationality $=$ Expatriates

c. Predictors: (Constant), PIED, POS

Table 12. Expatriates PIED-POS-AC Coefficients ${ }^{\mathrm{a}, \mathrm{b}}$

\begin{tabular}{|c|c|c|c|c|c|c|}
\hline \multirow[t]{2}{*}{ Model } & & \multicolumn{2}{|c|}{ Unstandardized Coefficients } & \multirow{2}{*}{$\begin{array}{l}\text { Standardized } \\
\text { Coefficients } \\
\text { Beta }\end{array}$} & \multirow[t]{2}{*}{$\mathrm{t}$} & \multirow[t]{2}{*}{ Sig. } \\
\hline & & $\mathrm{B}$ & Std. Error & & & \\
\hline \multirow{3}{*}{1} & (Constant) & .491 & .569 & & .862 & .393 \\
\hline & POS & .826 & .120 & 697 & 6.878 & .000 \\
\hline & PIED & .230 & .138 & .169 & 1.669 & .102 \\
\hline
\end{tabular}

a. Dependent Variable: AC

b. Selecting only cases for which Nationality $=$ Expatriates 
The multiple regression analysis carried out among Expatriate employees to investigate whether POS and PIED could significantly predict their AC scores indicates that the model explained $62.8 \%$ of the variance and that it is a significant predictor of Affective Commitment.

\section{Discussion}

Investigations on organization commitment from nationality perspective carried out in previous studies reported possible dissimilarities in the level of commitment on the basis of nationality even though these differences are not systematic (Gelade, Dobson \& Gilbert, 2006). Previous research pointed out that high labor mobility is the greatest challenge of Multinational Companies (MNC) in China (European Union SME Centre, 2015). This observation may give the impression that expatriates affective commitment is higher than that of HCN employees. The result of this study shows that even though the mean of expatriate employees $(\mathrm{M}=5.0435)$ is higher than that of national workers $(M=4.9944)$, this apparent difference is not statistically significant. Therefore it cannot be said that expatriates are more affectively committed to their organizations than HCNs are emotionally attached to their employers. The result of this research does not disagree with the findings of previous investigations as the dissimilarities observed based on nationality are not systematic (Gelade, Dobson \& Gilbert, 2006). The results of the analysis rather point out that the extreme mobility of labor in China may not be associated with the nationality but to the external environment such as the national economy, given the fact that for decades China has been the fastest growing economy.

The assessment of POS among HCNs and expatriates showed although the score of local employees $(\mathrm{M}=4.4441)$ is higher than that of expatriates $(\mathrm{M}=4.4022)$ it cannot be concluded that $\mathrm{HCN}$ employees are more receptive to the effort made by their organization to support or build a strong relationship with them as the p-value is greater than .05 (Appendix 8). The results of this test showed rather that there is no difference in the way local employees and expatriates perceive the effort of their organization to build relationship with them. Although Black, Mendenhall. and Oddou (1991) pointed out that expatriates workers are different from HCNs, on the basis of the psychological uncertainty and practical adjustments of the former, existing literature on the subject has not observed distinctive difference between the Perceived Organizational Support of the two categories of employees (Bashir, 2012; Takeuchi et al., 2009).

The assessment of PIED among HCNs and expatriates showed although the mean of local employees $(\mathrm{M}=$ 4.2119) is higher than that of expatriates employees $(M=3.9860)$ it cannot be concluded that HCNs respond more positively to organizational support effort of theirs employers compared to their expatriate counterparts as the p-value is greater than .05 . The results of this test show rather that there is no difference in the way expatriates and HCNs perceive investment in employee development. Zhang, Tsingan, \& Zhang (2013) observed that the way Chinese workers respond to investment in employees development is different from the way employees react in other countries, specifically in the West. However, their studies did not report specifically Host Country Nationals (HCNs) and expatriates workers.

The assessment of the combined effect of POS and PIED on AC showed among HCNs and expatriates workers showed that POS and PIED are significant predictors of Affective Commitment among both HCN and expatriate employees. However, Organizational Support, p<.001 among both the HCN and expatriates workers, predicts better Affective Commitment than Perceived Investment in Employee Development, p>.005. Expatriates are equally sensitive to their relationship with their organization as the HCNs. However, the model predicted better Affective Commitment among HCNs than it did among their expatriate counterparts, $63.3 \%$ for the HCNs against $62.8 \%$ for the expatriates, as shown in Table $7 \& 10$. In addition, while among HCNs both POS and PIED contributed significantly to the model, among expatriates only POS significantly contributed to the model and PIED did not $(\mathrm{p}=.102)$. The insignificant contribution of PIED to the model among expatriates could be explained by the fact they are in transition in the country and do not have a long-term plan to settle down.

This result comfort the observations made by Zhang, Farh \& Wang (2012) and Trompenaars (1996) who noticed a cultural influence in the separation of personal and professional lives. They observed that, as opposed to the West, professional life and private life significantly overlap in China. In other words the longing of Chinese workers for social exchange at the workplace is stronger than that of employees in the West.

\section{Recommendations for Human Resource Management and Directions for Future Research}

The model built for the purpose of this study indicated that the combination of POS and PIED is a significant predictor of AC. In other words, organizations by effectively supporting their employees and investing in their development should be able to significantly increase their affective commitment. Therefore, even though other factors could influence the affective commitment of employees in China it could be recommended that organizations firstly endeavor to effectively and intentionally support their workforce and then invest in their development. 
The assessment of the affective commitment of employees based on the nationality factor indicated that neither expatriates nor HCNs are more committed than the other. In other words none of these categories is predisposed to be more committed than the other. Therefore organizations should not privilege one category over the other in the attempt of minimizing costs.

Even though neither HCNs nor expatriate workers are predisposed to have a stronger commitment than the other group, the way these two categories of employees respond to the effort of their employers to increase their affective commitment is not the same. Expatriate workers seem to be less interested in investment in employee development and more organizational support. In formulating and implementing human resource practices to increase employees' affective commitment, managers should only seek to build a strong relationship with expatriates. To be effective in increasing the affective commitment of HCNs, managers should first build a strong organizational support for their employees before attempting to invest in their development. The implementation of these recommendations will enable management not only to avoid waste of resources but also to be more effective in their endeavor to implement human resource best practices.

Some scholars reported differences in the level of commitment on the basis of nationality. In this study it was observed that in China nationality is not a significant factor that impacts affective commitment. There are certainly reasons that explain this situation in China. Future researchers could attempt to identify the reasons why nationality is not a determinant factor that influences affective commitment.

POS and PIED could explain $62.8 \%$ to $63.3 \%$ of the variance in AC meaning that $36.7 \%$ to $37.2 \%$ of the variance remains unexplained. Future studies could attempt to identify determinant influencors of AC in China.

\section{Conclusion}

Existing literature reported that employee turnover is particularly high in China and this observation may give the impression that Chinese are generally less committed to their organizations than workers from other countries. This study demonstrated that in China HCNs are as committed as the expatriate employees. It also revealed the combination of organizational support and investment in employee development is a significant predictor of affective commitment.

It was observed that though affective commitment is significantly predicted by the combination of POS and PIED, HCNs respond more favorably to investment in employee development if organizational support is effectively implemented. However, expatriate workers are more open to organizational support and less receptive to investment in employee development. Organizations that seek to be successful in their endeavor to increase the affective commitment of the workforce should take these observations in consideration, though more light should be thrown on the factors that influence the employees' affective commitment in China.

\section{References}

Arthur, J. B. (1994). Effects of Human Resource System on Manufacturing Performance and Turnover. Academy of Management Journal, 37, 670-687.

Bashir, S. (2012). Perceived organizational support and the cross-cultural adjustment of expatriates in the UAE, Education, Business and Society. Contemporary Middle Eastern Issues, 5, 63-82. https://doi.org/10.1108/17537981211225862

Benote, A., \& King, R. (2016). Greater China Employee Intentions Report. Michaelpage. Retrieved from http://www.michaelpage.com.cn/sites/michaelpage.com.cn/files/

Bidisha, L. D., \& Mukulesh, B. (2013). Employee Retention: A Review of Literature. Journal of Business and Management, 14, 08-16.

Black, J. S., Mendenhall, M., \& Oddou, G. (1991). Toward a Comprehensive Model of International Adjustment: An Integration of Multiple Theoretical Perspectives. Academy of Management Review, 16, 291-317. https://doi.org/10.5465/amr.1991.4278938

Bokor, A., Szőts-Kováts, K., Csillag, S., Bácsi, K., \& Szilas, R. (2007). Emberi erőforrás menedzsment. Budapest: Aula Kiadó.

Bruning, N. S., \& Snyder, R. A. (1983). Sex and Position as Predictors of Organizational Commitment. Academy of Management Journal, 26, 485-491.

Chen, Z. X., Aryee, S., \& Lee, C. (2005). Test of a Mediation Model of Perceived Organizational Support. Journal of Vocational Behavior, 66, 457-470. https://doi.org/10.1016/j.jvb.2004.01.001

Eisenberger, R., Huntington, R., Hutchison, S., \& Sowa, D. (1986). Perceived Organizational Support. Journal of 
Applied Psychology, 71. 500-507. https://doi.org/10.1037/0021-9010.71.3.500

Gelade, A. G., Dobson, P., \& Gilbert P. (2006). Effect of Economy, Product Personality, or Consequence of Culture? Journal of Cross-Cultural Psychology, 37, 542-556. https://doi.org/10.1177/0022022106290477

George, J. M., Reed, T. F., Ballard, K. A., Colin, J., \& Fielding, J. (1993). Contact with AIDS patients as a source of work-related distress: Effects of organizational and social support. Academy of Management Journal, 36, 157-171.

Gutman, P., New, M., \& Stevenson, P., (2016). Tackling Trends in Turnover. Mercer Webcast Series. Retrieved from https://www.mercer.com/content/dam/mercer/attachments/global/webcasts/

Gutteridge, T. G., Leibowitz, Z. B., \& Shore, J. E. (1993). When Careers Flower, Organizations Flourish. Training and Development Journal, 47, 24-29.

Harter J., \& Adkins, A. (2015). What great managers do to engage employees. Havard Business Review. Retieved from https://hbr.org/2015/04/what-great-managers-do-to-engage-employees

Ichniowski, C., Shaw, K., \& Prennushi, G. (1997). The Effects of Human Resource Management Practices on Productivity. American Economic Review, 87, 291-313.

Jingxi, X. (2015). Turnover up slightly in workplaces. China Daily USA. Retrieved from http://usa.chinadaily.com.cn/epaper/2015-12/21/content_22763852.htm

Kate, W., \& Masako, T. (2002). Reframing Organizational Commitment within a Contemporary Careers Framework (1st ed.). Ithaca, NY.

Krishnaveni, R., \& Ramkumar, N. (2008). Revalidation Process for Established Instruments: A Case of Meyer and Allen's Organizational Commitment Scale. The Icfai Journal of Organizational Behavior, 5, 1-16.

Kuvaas, B., \& Dysvik, A. (2009), Perceived investment in employee development, intrinsicmotivation and work performance. Human Resource Management Journal, 19, 217-236. https://doi.org/10.1111/j.1748-8583.2009.00103.x

Kuvaas, B., Dysvik, A., \& Buch R. (2016). Perceived investment in employee development and taking charge. Journal of Managerial Psychology, 31, 50-60. https://doi.org/10.1108/JMP-04-2013-0117

Lee, C. H., \& Bruvold, N. T. (2003). Creating value for employees: investment in employee development". International Journal of Human Resource Management, 14, 981-1000. https://doi.org/10.1080/0958519032000106173

Lehman, A., O'Rourke, N., Hatcher, L., \& Stepanski, E. J. (2005). JMP for basic univariate and multivariate statistics: A step-by-step guide (2nd ed.). Cary, North Carolina, NC: SAS Institute Inc.

Lok, P., \& Crawford J. (2004). The effect of organizational culture and leadership style on job satisfaction and organizational commitment. Journal of Management Development, 23, 321-338. https://doi.org/10.1108/02621710410529785

Loscocco, K. A. (1990). Reactions to blue-collar work: A comparison of women and men. Work and Occupation, 17, 152-177. https://doi.org/10.1177/0730888490017002002

MacDuffie, J. P. (1995). Human Resource Bundles and Manufacturing Performance: Organizational Logic and Flexible Production Systems in the World Auto Industry. Industrial And Labor Relations Review, 48, 197-221. https://doi.org/10.1177/001979399504800201

Mathieu, J. E., \& Zajac, D. M. (1990). A review and meta-analysis of the antecedents, correlates, and consequences of organizational commitment. Psychological Bulletin, 108, 171-194. https://doi.org/10.1037/0033-2909.108.2.171

Maxwell J. C. (2011). The Five Levels of Leadership: proven steps to maximize your potential (1st ed.).New York, NY: Hachette Book Group.

Meyer, J. \& Allen, N. (1991). A three-component conceptualization of organizational commitment. Human Resources Management Review, 1, 81-89. https://doi.org/10.1016/1053-4822(91)90011-Z

Meyer, J. P., \& Allen, N. (2004). TCM Employee commitment survey academic users guide. Retrieved from http://employeecommitment.com/TCM-Employee-Commitment-Survey-Academic-Package-2004.pdf

Meyer, J. P., \& Allen, N. J. (1997). Commitment in the Workplace: Theory, Research, and Application (2nd ed.). California, CA: Sage, Thousand Oaks. 
Meyer, J. P., Stanley, D. J., Herscovitch, L., \& Topolnytsky, L. (2002). Affective, continuance and normative commitment to the organization: A meta-analysis of antecedents, correlates and consequences. Journal of Vocational Behavior, 62, 20-52. https://doi.org/10.1006/jvbe.2001.1842

Mita, M., Aarti K. \& Ravneeta, D. (2014). Study on Employee Retention and Commitment. International Journal of Advance Research in Computer Science and Management Studies, 2, 154-164.

Mosadeghrad, A. M., Ferlie E., \& Rosenberg, D (2008). A study of the relationship between job satisfaction, organizational commitment and turnover intention among hospital employees. Health Services Management Research, 21, 211-227. https://doi.org/10.1006/jvbe.2001.1842

Mowday, R. T., Porter, L. M., \& Steers, R. M. (1982). Employee-organization linkages: The psychology of commitment, absenteeism, and turnover (1st ed.). New York,NY: Academic Press.

Odubanjo, D. (2015). Employee Retention Strategies In Gauff Consultants (Nigeria) Limited (Master's thesis, Dublin Business School, Dublin, Ireland). Retrieved from https://esource.dbs.ie/bitstream/handle/10788/2488/

Qammar, A., Khan M. Z., \& Siddique. M. (2006). Impact of demographics on organizational support and employees motivation. Journal of Management Sciences, 1, 87-98.

Rayani, A, (2015). Generational Differences in Perceived Supervisory Support (Master's thesis, San Jose State University, California, USA). Retrieved from

https://scholarworks.sjsu.edu/cgi/viewcontent.cgi?article=8156\&context=etd_theses

Reich, R. B. (1991). The work of nations: preparing ourselves for 21 st century capitalism (1st ed.). New York, NY: Knopf.

Rhoades, L., \& Eisenberger, R. (2002). Perceived Organizational Support: A Review of the Literature. Journal of Applied Psychology, 87, 698-714. https://doi.org/10.1037/0021-9010.87.4.698

Rhoades, L., Eisenberger, R., \& Armeli, S. (2001). Affective Commitment to the Organization: The Contribution of Perceived Organizational Support. Journal of Applied Psychology, 86, 825-836. https://doi.org/10.1037/0021-9010.86.5.825

Rothwell, W. J., \& Kazanas, H. C. (1989). Strategic human resource development. New Jersey, NJ: Prentice Hall.

Settoon, R. P., Bennett, N., \& Liden, R. C. (1996). Social Exchange in Organization: Perceived Organizational Support, Leader-Member Exchange and Employee Reciprocity. Journal of Applied Psychology, 81, 219-227. https://doi.org/10.1037/0021-9010.81.3.219

Shore, L. M., \& Wayne, S. J. (1993). Commitment and Employee Behavior: Comparison of Affective Commitment and Continuance Commitment with Perceived Organizational Support. Journal of Applied Psychology, 78, 774-780. https://doi.org/10.1037/0021-9010.78.5.774

Takeuchi, R., Wang, M., Marinova, S. V., \& Yao, X. (2009). Role of Domain-Specific Facets of Perceived Organizational Support During Expatriation and Implications for Performance. Organization Science, 20, 621-634. https://doi.org/10.1287/orsc. 1080.0403

Thirapatsakun, T., Kuntonbutr, C., \& Mechinda, P. (2014). The relationships among job demands, work engagement, and turnover intentions in the multiple groups of different levels of perceived organizational supports. Universal Journal of Management, 2, 272-285.

Trompenaars, F., \& Hampden-Turner, C. (2012). Riding the Waves of Culture (3rd ed.). New York, NY: McGraw-Hill.

Tuck, M. G. (2014). The impact of investment in employee development on the fulfilment of the psychological contract and organizational outcomes (Master's thesis, University of Canterbury, Christchurch, New Zealand). Retrieved from https://ir.canterbury.ac.nz/handle/10092/11369

Woods, S., \& De Menezes, L. (1998). High commitment management in the uk: evidence from the workplace industrial relations survey and employers manpower and skills practices survey. Human Relations, 51, 485-515. https://doi.org/10.1177/001872679805100403

Youndt, M., Snell, S., Dean, J. \& Lepak, D. (1996). Human ResourceManagement, Manufacturing Strategy, and Firm Performance. Academy of Management Journal, 39, 836-866.

Yunus, F. (2010). Statistics using SPSS: An integrative approach, second edition. Journal of Applied Statistics, 


\section{7, 2119-2120. https://doi.org/10.1080/02664760903075515}

Zhang, R., Tsingan, L., \& Zhang, L. (2013). Role stressors and job attitudes: A mediated model of leader-member exchange. The Journal of Social Psychology, 153, 560-576.

https://doi.org/10.1080/00224545.2013.778812

Zhang, Y., Farh, J. L., \& Wang, H. (2012). Organizational antecedents of employee perceived organizational support in China: a grounded investigation. The International Journal of Human Resource Management, 23, 422-446. https://doi.org/10.1080/09585192.2011.560886

\section{Appendix A}

Affective commitment- Nationality Independent Samples Test

\begin{tabular}{|c|c|c|c|c|c|c|c|c|c|c|}
\hline & \multicolumn{2}{|c|}{$\begin{array}{c}\text { Levene's Test for } \\
\text { Equality of Variances }\end{array}$} & \multicolumn{7}{|c|}{ t-test for Equality of Means } \\
\hline & & \multirow[t]{2}{*}{$\mathrm{F}$} & \multirow[t]{2}{*}{ Sig. } & \multirow[t]{2}{*}{$\mathrm{t}$} & \multirow[t]{2}{*}{ df } & \multirow[t]{2}{*}{$\begin{array}{c}\text { Sig. } \\
\text { (2-tailed) }\end{array}$} & \multirow[t]{2}{*}{$\begin{array}{c}\text { Mean } \\
\text { Difference }\end{array}$} & \multirow[t]{2}{*}{$\begin{array}{l}\text { Std. Error } \\
\text { Difference }\end{array}$} & \multicolumn{2}{|c|}{$\begin{array}{l}\text { 95\% Confidence } \\
\text { Interval of the } \\
\text { Difference }\end{array}$} \\
\hline & & & & & & & & & Lower & Upper \\
\hline & $\begin{array}{l}\text { Equal variances } \\
\text { assumed }\end{array}$ & 3.953 & .048 & & & .829 & -.04908 & .22692 & & .39786 \\
\hline & $\begin{array}{l}\text { Equal variances } \\
\text { not assumed }\end{array}$ & & & -.193 & 66.676 & .848 & -.04908 & .25436 & -.55683 & .45866 \\
\hline
\end{tabular}

\section{Appendix B}

Perceived Organization Support-Nationality Independent Samples Test

\begin{tabular}{|c|c|c|c|c|c|c|c|c|c|c|}
\hline & \multicolumn{2}{|c|}{$\begin{array}{c}\text { Levene's Test for } \\
\text { Equality of Variances }\end{array}$} & \multicolumn{7}{|c|}{ t-test for Equality of Means } \\
\hline & & \multirow[t]{2}{*}{ F } & \multirow[t]{2}{*}{ Sig. } & \multirow[t]{2}{*}{$\mathrm{t}$} & \multirow[t]{2}{*}{ df } & \multirow[t]{2}{*}{$\begin{array}{c}\text { Sig. } \\
\text { (2-tailed) }\end{array}$} & \multirow[t]{2}{*}{$\begin{array}{c}\text { Mean } \\
\text { Difference }\end{array}$} & \multirow[t]{2}{*}{$\begin{array}{l}\text { Std. Error } \\
\text { Difference }\end{array}$} & \multicolumn{2}{|c|}{$\begin{array}{l}95 \% \text { Confidence } \\
\text { Interval of the } \\
\text { Difference }\end{array}$} \\
\hline & & & & & & & & & Lower & Upper \\
\hline & $\begin{array}{l}\text { Equal variances } \\
\text { assumed }\end{array}$ & \multirow[t]{2}{*}{3.822} & \multirow[t]{2}{*}{.052} & .218 & & .828 & .04188 & .19203 & -.33633 & \\
\hline & $\begin{array}{l}\text { Equal variances } \\
\text { not assumed }\end{array}$ & & & .195 & 66.780 & .846 & .04188 & .21489 & -.38707 & .47083 \\
\hline
\end{tabular}

\section{Appendix C}

Perceived Investment in Employee Development-Nationality Independent Samples Test

\begin{tabular}{|c|c|c|c|c|c|c|c|c|c|c|}
\hline & \multicolumn{2}{|c|}{$\begin{array}{c}\text { Levene's Test for } \\
\text { Equality of Variances }\end{array}$} & \multicolumn{7}{|c|}{ t-test for Equality of Means } \\
\hline & & \multirow[t]{2}{*}{$\mathrm{F}$} & \multirow[t]{2}{*}{ Sig. } & \multirow[t]{2}{*}{$\mathrm{t}$} & \multirow[t]{2}{*}{ df } & \multirow[t]{2}{*}{$\begin{array}{c}\text { Sig. } \\
\text { (2-tailed) }\end{array}$} & \multirow[t]{2}{*}{$\begin{array}{c}\text { Mean } \\
\text { Difference }\end{array}$} & \multirow[t]{2}{*}{$\begin{array}{l}\text { Std. Error } \\
\text { Difference }\end{array}$} & \multicolumn{2}{|c|}{$\begin{array}{l}95 \% \text { Confidence } \\
\text { Interval of the } \\
\text { Difference }\end{array}$} \\
\hline & & & & & & & & & Lower & Upper \\
\hline & $\begin{array}{l}\text { Equal variances } \\
\text { assumed }\end{array}$ & .526 & .469 & & & & & .17753 & & \\
\hline & $\begin{array}{l}\text { Equal variances } \\
\text { not assumed }\end{array}$ & & & 1.193 & 70.043 & .237 & .22594 & .18940 & -.15180 & .60367 \\
\hline
\end{tabular}

\section{Copyrights}

Copyright for this article is retained by the author(s), with first publication rights granted to the journal.

This is an open-access article distributed under the terms and conditions of the Creative Commons Attribution license (http://creativecommons.org/licenses/by/4.0/). 